\title{
The Water-Use of Mining Towns and Their Villages in Medieval Hungary: The Example of Kremnica"
}

András Vadas

vol. 10, 2021, 2, pp. 37-54

DOI: https://doi.org/10.33542/CAH2021-2-02

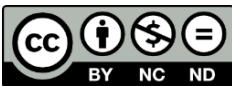

The paper addresses the long-term impact of mining towns and the villages under the authority of these towns on the waterscapes in the northern mining area of the medieval Kingdom of Hungary (presentday Slovakia). The paper focuses on the privileging practices of the settlers of villages founded by burghers of a medieval mining town, Kremnica. The paper argues that analysing Kremnica's practice in settling the towns' surroundings may on the one hand shed light on the privileges of the settlers of the town itself, and on the other, be crucial to understanding a previously neglected environmental impact of mining in pre-modern times. The paper argues that while charters of privilege provided to mining towns seldom refer to the freedom to exploit water, the towns' settlers did use the waterways to their benefit. In arguing for this the paper discusses the freedoms of the settlers' villages of Kremnica in the fourteenth-fifteenth centuries. The freedom of settlers - or the leading of the settling process led to an increased pressure on waterways in mining town areas that had lasting consequences on the landscapes of these regions.

Keywords: Mining towns. Urban economy. Environmental history. Water mills. Privileges. Kremnica.

\section{Introduction}

Mining put just as significant a pressure on the landscapes in pre-modern times as it does nowadays. For the exploitation of a metal ore discovered in the soil, not only had a certain piece of land to be designated to start bringing the ore to the surface, but major infrastructural interventions were prerequisites to the exploitation of this resource, seriously affecting the environment. Mining regions of Central Europe, for geological reasons - the discussion of which falls outside the scope of the present paper - are in the majority of cases concentrated in hilly and mountainous areas. These areas, because of the climatic features of the region, were densely forested compared to the lowland areas which, as has recently been demonstrated, were already significantly less forested a millennium ago. ${ }^{1}$ The dense forest cover prevalent and the relatively limited area and low quality of land for agricultural activities, as well as the concentrated industrial activities, created a special environment, in which the proximity and the accessibility of different resources - such as water - proved to be a crucial factor in the settlement process. ${ }^{2}$

\footnotetext{
The research was supported by the Bolyai János Research Scholarship of the Hungarian Academy of Sciences.

Dr András Vadas, Institute of Historical Studies, Faculty of Humanities, Eötvös Loránd University, Budapest, Hungary; vadas.andras@btk.elte.hu; ORCID iD: 0000-0001-5402-1104

1 For the landscapes of Central Europe in general, see: FERENCZI et al. Long-Term Environmental Changes, 37-47. SZABÓ, The Extent and Management of Woodland, 219-237. VADAS, Geography, Natural Resources and Environment.

2 CEMBRZYŃSKI, "Gold Rush" or "Considered Investment", 59-72. On industrial energy and mining towns, see: LUCAS, Industrial Milling in the Ancient and Medieval Worlds, 1-30; and for Hungary, see: TEKE, L'energia idraulica, 335-341.
} 
The marginal, mountainous areas of the Carpathian Basin formed the frontier of the medieval Kingdom of Hungary, and as such were sparsely populated until the second half of the Árpádian period (1000-1301). ${ }^{3}$ These areas, however, soon became attractive for several reasons, many of which are directly connected to the availability of natural resources, such as wood, pasture and, not least, ores. In the first half of the Árpádian period, precious metal ores, that proved to be the main driving forces of the settling of the mountain areas of what is today's Slovakia, were mostly - but not exclusively - exploited by panning, but from the thirteenth century onwards, written sources testify to the intensification of complex mining activities in the area. This went with the formation of settlements, which were prerequisites to the exploitation of gold, silver and other metal deposits in present-day Slovakia.

In founding mining towns as well as settlers' villages the landlords - in many cases the rulers themselves - had to provide certain privileges to attract and help newcomers to set up their lives in their new homes. ${ }^{4}$ Most of these privileges were directly related to the right to exploit what nature provided. The paper looks at one of these resources that previous research may have attributed less importance to, but which probably was a key factor in settling and in exploiting the mining goods: that is, the right to exploit waterways. In understanding the water-related privileges of these newly founded settlements the primarily focus will not be on the mining towns' privileges themselves as they provide relatively little background on that, but the paper will attempt to look at the privileges granted to villages, or rather its settling leaders (locatores, or sculteti), founded by mining town burghers. ${ }^{5}$ This as I shall argue may help us to identify the norms of the exploitation of waterways in mining regions of medieval Hungary, as well as shedding light on the ways the environment was transformed with the settling of these areas.

\section{Mining Town Privileges and Water-Use}

There is significant literature on the privileging of settlements in the thirteenth and fourteenth centuries in Central Europe, and in the Kingdom of Hungary, ${ }^{6}$ and recently, several detailed studies have addressed the privileges of mining towns specifically. ${ }^{7}$ These charters of privileges often refer to the freedom to exploit natural resources lying within the limits of the settlements. Because of the need for timber to start mining activity, as well as to build dwellings, the motivations behind providing freedom to exploit timber resources is somewhat unambiguous. Thus, taking note of such privileges was almost as important to consider as the freedom to exploit the mineral resources. The privileges therefore in most cases address the issue of mining - that is, the right to prospect and exploit mineral resources - and regulate the usage of the surrounding

\footnotetext{
3 BATIZI, Mining in Medieval Hungary, 166-181.

4 SZENDE, lure Theutonico, 360-379.

5 WEISZ, Mining Town Privileges; and the relevant chapters in: ŠTEFÁNIK - LUKAČKA, Lexikon stredovekých (both with further literature).

6 FÜGEDI, Középkori magyar városprivilégiumok, 32-56. SZENDE, Power and Identity, 27-68. SZENDE, Mennyit ér a kiváltság, 285-340. ZSOLDOS, Károly és a városok, 267-283.

7 WEISZ, A nemesércbányászathoz kötődő privilégiumok, 141-161. WEISZ, A bányaváros mint önálló várostípus, 31-57; and most recently: WEISZ, Az alsó-magyarországi bányavárosok kiváltságai, 21-48.
} 
forested areas and their timber. ${ }^{8}$ In processing the ores unearthed in the mines, however, another resource, water, was also of crucial importance.

Mills, up to the invention of steam engines, were one of the most important sources of industrial power. ${ }^{9}$ Even though water energy was fundamental in many ways in mining - to saw the timber to be built into the shafts, in providing energy for dewatering machines, to crush the ore brought to the ground, and not least to provide the burghers with flour - Hungarian mining town privileges, with two exceptions, fail to refer to the right of settlers to build the mills on rivers within the town limits which would have fulfilled most of the above listed needs. ${ }^{10}$ However, as I have argued elsewhere, despite the lack of express reference to the right of the settlers of mining towns to build mills, it was probably customary for the townsfolk to use water for their own benefits.

To gain a more nuanced view of the rights of the settlers of the new mining towns to build on waterways, the case of the town of Kremnica will be discussed in more depth. In doing so the primary focus will be on the rights of the settlers' villages founded by the townspeople in the surroundings of Kremnica as the founding and privilege charters of these settlements preserve important points that may also be indicative of the local urban practices in exploiting this, in the mining town environments, crucial resource.

\subsection{Kremnica and Its Streams - Who Built What?}

Kremnica provides a prime case by which to understand the importance of waterways in the life of a mining settlement. It is even more relevant when considering the importance of the villages founded by mining towns and the usage of water in these settlements, as Kremnica within a few decades after its foundation had systematically started to extend its authority to the surroundings of the newly founded town. The townspeople of Kremnica founded a chain of settlements in the surrounding valleys to exploit the mineral and other resources there as well. Before presenting the waterrelated privileges provided to the settlers of these settlements, it is important to demonstrate the importance of water-related infrastructure in Kremnica. I will briefly survey the surviving documentary evidence that concerns the water mills within the borders of the town in order to show how, when and by whom these buildings were built, and how important they were to the town's development.

Before going into detail concerning the development of the mills in Kremnica, let me refer to the foundation of the town itself. The development of the town begins in 1328, when, on 1 November, King Charles I issued a privilege to its settlers. The Hungarian ruler enfranchised settlers who came from Kutná Hora (Kuttenberg) in Bohemia. Their settling in Hungary was probably initiated as part of the diplomatic meetings of Charles I and John of Luxemburg, the king of Bohemia in 1327. The miners and minters - who were probably mostly Germans and Italians respectively ${ }^{11}$ - and those who might settle in the future were provided with the rights that were essential to the

8 WEISZ, A bányaváros mint önálló várostípus, passim. WEISZ, A nemesércbányászathoz kötődő privilégiumok, 38-40. MALINIAK et al. Lesy $v$ dejinách Zvolenskej stolice.

9 See: LUCAS, Wind, Water Work.

10 For the privileges and water use, see: VADAS, A középkori Magyar Királyság bányavárosai, 483-506. For the importance of ore crushing mills in mining areas, see: FRÖHLICH, Středověké a raně novověké mlýny.

11 See e.g. the example of Petrus Gallicus de Siena: SZENDE, Királyi kényszer vagy közösségi akarat, 519. On him, see also: ZSOLDOS, Sienai ötvösböl szepesi alispán, 61. 
initiation of the mining activity. The document's first point provides the settlers with the freedom to use the uninhabited lands and forests for their benefit within a two-mile radius. ${ }^{12}$ The document, however, includes stipulations that were anything but usual in the medieval Hungarian legal environment. To wit, in questions not covered in the privilege, the rights of Kutná Hora are identified as authoritative. ${ }^{13}$ Accordingly, the charter fails to discuss numerous aspects of the foundation of the town, including the right to use the waters found within the borders of the settlement. The burghers of Kutná Hora in general could use the privileges provided in the summary of the medieval Bohemian royal mining right (Bergrecht), the so-called lus regale montanorum. ${ }^{14}$ This legal text, however, also remains silent on water rights. Despite this lack of data - as I shall demonstrate shortly - similarly to in Kremnica, numerous burghers from Kutná Hora built and owned mills within the limits of their town. ${ }^{15}$

Nonetheless the spatial organization of Kremnica - that spread along two minor streams the confluence of which was at the centre of the town - shows that water was a crucial resource. In many of the urban privileges it is the possibility of the fish catch that was the most important water-related utility, but in the case of mining towns it certainly was the right of the settlers to exploit waterways for energy production, that is to erect water mills. It is well reflected in the case of Kremnica and the villages founded by the townspeople, where water mills - as I shall discuss here - were of key importance, and probably one of the main motivations behind the founding of a number of the villages within Kremnica's town limits.

The first document that refers to water mills in Kremnica was issued in 1331. By this time a good number of mills operated within the boundaries of the recently founded town. ${ }^{16}$ The document is a pledge contract concluded between a certain Stephen Marsilii and leclinus of Olf, both probably burghers of Kremnica, in front of Lupoldus (Hyppolit), master of minting and chamber count of Kremnica, ${ }^{17}$ as well as judges and jurors of the town. While the name of Marsilii suggests an Italian origin, a group whose presence is less frequently discussed in relation to mining towns in Hungary, leclinus may be one of the settlers who arrived from the town of Olpe in the Rhineland. ${ }^{18}$ According to the contract, leclinus of Olf agreed to repay his debt representing a significant amount of cash and other goods, according to the details specified in the document, while Marsilii accepted a number of immovable goods from leclinus as a pledge. As customary for similar pledge contracts, apart from the debt-scheduling, the document also lists the

12 "Hospites nostri de ipsa Cremnychbana ad duo miliaria terras sive silvas habitatoribus destitutas, vicinas eis et contiguas, collacioni nostre subiectas absque preiudicio iuris alieni cultui ipsorum et usui applicandi liberam habeant facultatem" - JUCK, Výsady miest a mestečiek na Slovensku, p. 115, no. 136.

13 STRÄTZ, Kuttenberger Bergordnung, 1594.

14 For its edition, see: PFEIFER, lus regale montanorum, 266-435. On the codification process, see: von STERNBERG, Umrisse einer Geschichte der böhmischen Bergwerke. ZYCHA, Das böhmische Bergrecht (with another edition of the text in the second volume). And more recently: PFEIFER, Ius regale montanorum. JAN, Václav II. a struktury panovnické moci. I am indebted to Renáta Skorka for drawing my attention to these works.

15 See the database: http://vodnimlyny.cz. See also: VAVRUŠKOVÁ, Po stopách mlynár̆ů v Kutné Hoře, 14-18. Accessed 6 October 2021. https://www.cms-kh.cz/po-stopach-mlynaru-v-kutne-hore. The late medieval Bergrecht of Kremnica nonetheless contained a clause on ore crushing mills: ČELKO, Das Stadt- und Bergrecht von Kremnitz, 311-313.

16 Magyar Nemzeti Levéltár Országos Levéltára (hereinafter MNL OL), Diplomatikai Fényképgyújtemény (hereinafter DF) 250 152. Edited in: MATUNÁK, Z dejin Slobodného, pp. 455-457, no. 4.

17 On him, see: ŠTEFÁNIK, Italian Involvement in Metal Mining, 19-20.

18 MINÁRČIC, Metačná listina svätoantonského panstva z roku 1266, 50. 
immovable estates that were pledged. Amongst these immovables, and in order to identify these buildings, a number of mills are mentioned in the contract in two areas in the town, in the so-called Soler ${ }^{19}$ and Collner ${ }^{20}$ valleys (see Fig. 1), both formed by branches of the Kremnický Stream, the only significant waterway within the borders of Kremnica. ${ }^{21}$

The document lists the following water mills:

- a mill in the Soler valley owned by leclinus ${ }^{22}$ with one sixth of the river; ${ }^{23}$

- the mill of Kadold ${ }^{24}$ in the Soler valley:25

- two mills and a furnace owned by leclinus in the Soler valley, around the mill of Kadold; ${ }^{26}$

- a mill next to the estate of Mazaldrus owned by leclinus in the Collner valley;

- the mill of the judge of Pukano (Pukanec) ${ }^{27}$ in the Collner valley;

- the mill of leclinus next to that of the judge of Pukano in the Collner valley;

- an ore stamp mill called Kolbe in the Collner valley above the previous one;

- an ore stamp mill owned by Nicholas Putner, probably also in the Collner valley.

19 Referred to today as Skalka Stream, an east-west running river within the borders of Kremnica, and a tributary to the Kremnický Stream. More mills are indicated by this stream by György Györffy (GYÖRFFY, Az Árpád-kori Magyarország, vol. 1, 455.) as well as: ŠTEFÁNIK, Kremnica, 221.

20 North-south running of the Kremnický Stream.

21 GYÖRFFY, Az Árpád-kori Magyarország, vol. 1, 454-456. ŠTEFÁNIK, Kremnica, 221 and 223.

22 He may be identical with a man referred to as a burgher of Hybe: BORSA, A Szent-Iványi család levéltára, p. 27, no. 38 .

23 Probably meaning the right to one sixth of the water of the river.

24 As an urburarius of Pukanec: KRISTÓ, Anjou-kori oklevéltár, vol. 29, pp. 296-296, no. 480. MNL OL, DF 237 039. He owned a mill by the Büksavnica Stream close to Nová Baňa, to be discussed hereafter. Later, he became chamber count of Kremnica: "Komorskí grófi Kremnice". Accessed 25 September 2021. http://www. corycats.sk/mint/index.php?go=grofi_is.

25 Later called the Upper Mill $(1365,1366,1372,1373)$ which had four wheels by 1373 . Cf. MNL OL, DF 249435.

26 They probably do not represent two mills, but rather a single mill with two wheels.

27 For Pukano- Bakabánya: FEHÉRTÓl, RATA és TILO, 66. KISS, Földrajzi nevek etimológiai szótára, 76 (Bakabánya). 


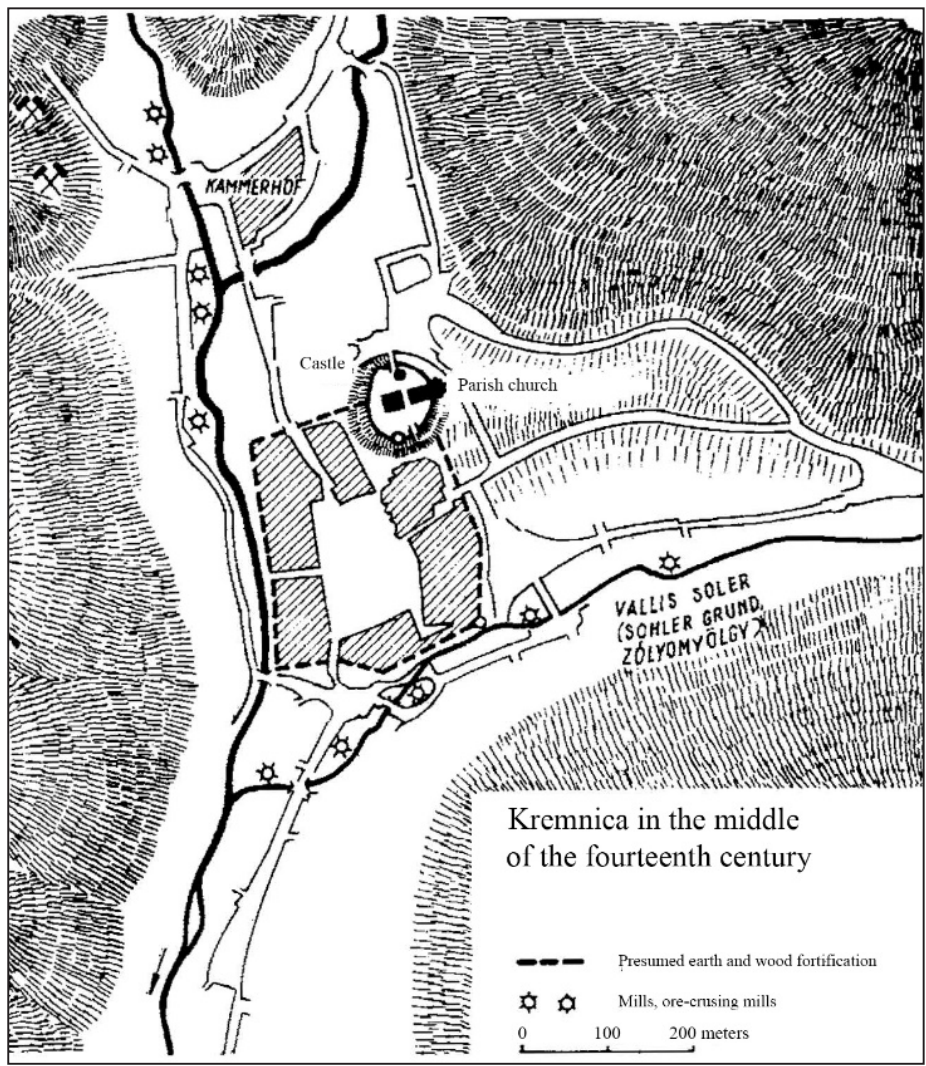

Figure 1: The mills and the urban topography of Kremnica in the mid-fourteenth century (after György Györffy)

The above list provides some important lessons from the point of view of the main question of this paper. First, water mills probably began to be erected within the town boundaries from the moment settling began. Based, however, on the number of mills and their ownership by burghers in other towns, it is very possible that some of the mills even predate the issuing of the foundation charter. ${ }^{28}$ The half dozen grain mills and the further ore stamp mills and furnaces suggest that the settlement became significant within a very short period. Considering that by its very nature the contract could not have recorded every mill, the population of the town may have grown rapidly, representing one of the most successful town foundations in the region at the turn of the thirteenth century. ${ }^{29}$ Second, the ownership of these mills is important. Somewhat typically, the picture is anything but clear, as there is little information on the people

28 See for instance the case of Nová Baňa: VADAS, A középkori Magyar Királyság bányavárosai, 53-55.

29 For the estimate of the population: PAULINYI, A Garam-vidéki bányavárosok lakosságának lélekszáma, 351378. 
mentioned in the above and other similar documents. However, it is clear mills were either in the hands of the burghers of Kremnica or held by burghers in other nearby mining towns. ${ }^{30}$ Third, the document is one of the most important sources on the early topography of the mining town. Based on the contract, it seems clear that the town grew rapidly from early on and parts of the settlement were found over a relatively extended area, within two small valleys, one running north-south and the other east-west. This layout of the town was certainly connected to the availability of water energy in the proximity or at the actual plot of the new settlers.

The number of mills as well as their relative situation could be identified based on the document; however, the source does not refer to their actual positions along the two streams. The Hungarian historian, György Györffy as well as Slovak researchers mostly use this contract when trying to visualize the extent of the town in the period of its foundation. ${ }^{31}$ Györffy suggested that there were five water mills along each of the streams. In the case of the Collner valley this number is probably right. In the Soler valley, however, there were probably only three mills, two of which had a single wheel while the third, apart from two wheels that ground grain and a third that crushed ore, was placed within the same building. ${ }^{32}$ Having wheels for different functions housed under the same roof was not exceptional and was, in fact, quite normal in the late medieval period. Most importantly, all these mills were already operating within three years after the foundation charter of the town was issued. This suggests that the new settlers did practice the right to build on the waterways which, it seems, was crucial for the local economy. The latter can be testified to in the fact that these mills according to all odds could not satisfy the local needs.

\subsection{Settlers' Villages in the Surroundings of Kremnica and Water-Use}

Apart from the mills built within the town itself, from the middle of the fourteenth century onwards, i.e., within no more than two decades after the town's foundation, mills were also built at villages founded by or with the involvement of the burghers of Kremnica within the limits (the two-mile radius) or close to the town. ${ }^{33}$ They not only founded new settlements, but also extended their power to already existing smaller villages.

One of the first newly founded villages may have been Kunešov (in Latin: Villa St Michaelis, in Hungarian: Szentmihály), settled by a certain Vernher of Potska in 1342. Apart from initiating the settling, he and his heirs received jurisdiction over the villagers. ${ }^{34}$ The settlers did not receive the rights of Kremnica, but those of Žilina where the privilege dated back to $1321 .{ }^{35}$ The settlers of the newly founded Kunešov, however, could enjoy a freedom that was not specified by King Charles I for Žilina, but

30 Such as the judge of Pukanec and Kadold, who was also active at Pukanec.

31 GYÖRFFY, Az Árpád-kori Magyarország, vol. 1, 454-456. ŠTEFÁNIK, Kremnica, 221 and 223.

32 "Item molendinum circa Mazaldrum situm et infra molendinum judicis de Pukano ipsum Jeclinum contigentem, pro quinquaginta marcis eciam Regii pagamenti. Item unum confum, quod wlgariter Kolbe dicitur in eadem aqua inferius sita et ibidem Nycolaus dictus Putner habet unum contum, pro quinque marcarum pagamenti estimamus... and Primo unam rotam cum sexta parte aque in valle Soler pro triginta marcarum pagamenti. Item duas Rotas et chazam in superflui aqua circa molendinum Kadoldi sitam, pro quadraginta marcarum Regii pagamenti." MATUNÁK, Z dejin Slobodného, pp. 455-457, no. 4.

33 For the hospes-villages and their foundations in Upper Hungary, see: KÖRMENDY, Melioratio terrae.

34 MATUNÁK, Z dejin Slobodného, p. 458, no. 6; see also here: pp. 457-458, no. 5.

35 JUCK, Výsady miest a mestečiek na Slovensku, pp. 97-98, no. 110. 
was additionally granted to the locator and the settlers of Kunešov, namely the right to build along the water. ${ }^{36}$ This likely signified that soon after the foundation of Kremnica, its burghers realized how important it was to ensure this right, which as discussed was not specified in the town's charter of privilege, but was nonetheless probably treated as an existing right from early on. In the coming decades, numerous new villages were founded around (mostly north of) Kremnica, and the contracts connected to their foundations are all indicative of the liberties that the settlers could usually enjoy. Similarly to Kunešov, the village of Sklené (Hungarian: Szklenó) was founded with the support of Kremnica by the nobles of the later abandoned Felsőmutna under the leadership of the locator Peter Glaser. Just as the settlers of Kunešov, the people who chose to set up their lives at Sklené in $\mathbf{1 3 6 0}$ were also granted the freedoms of Žilina. The charter emphasized that the new villagers received the freedom to build their own mills among their other rights. ${ }^{37}$ It is certainly interesting that the document lists this right as one that belonged to the freedoms provided by the privilege of Žilina, which as was discussed in the above lines, was not the case.

One further village founded around that time was settled by a certain John (Johannes), hence the original name of the settlement, Johannesberg (called Kremnické Bane nowadays). ${ }^{38}$ The exact date of the foundation is unknown, but it probably occurred around the middle of the fourteenth century. John Göldner, a burgher of Kremnica, came into possession of the settlement in 1361. Apart from the right to build on the waterway, he also received a then four-wheeled mill that had been built in the settlement. ${ }^{39}$ When Göldner came into possession of the settlement, he also inherited the rights of Žilina for the settlement.

Yet another settlement foundation in the surroundings of Kremnica took place in 1364. The nobles in the above-mentioned settlement of Felsőmutna this time intended to found villages in the forests belonging to their rather extensive estates. The Mutna or by its Árpádian-period name Chernakou ${ }^{40}$ - forest lay in the southernmost area of historical Turóc County and was divided into two parts by the river bearing the same name as the county (Turiec by its modern name). ${ }^{41}$ The river proved to be an important asset in settling the area as its flow by far exceeded that of the rivers within the borders of Kremnica. This fact and the richly forested land were the most important factors in settling the area. The settling process itself took quite a while as in 1263, the land of Mutna Forest had been given to new settlers during the reign of King Béla IV in return for fishing and hunting services they provided the king. ${ }^{42}$ The area probably remained virtually uninhabited for a century, but in the middle of the fourteenth century, plans to settle the area were finally concluded. The settling was organized under the leadership

36 "Insuper judici praedicto et suis villanis contullimus, quod quantum in aqua sursum et deorsum poterunt aedificare, nemo eos audeat infestare." MATUNÁK, Z dejin Slobodného, p. 458, no. 6.

37 MATUNÁK, Z dejin Slobodného, pp. 459-461, no. 8.

38 On John/Johannes, see: ŠTEFÁNIK, Kremnica, 230.

39 MATUNÁK, Z dejin Slobodného, pp. 461-462, no. 9. Cf. ŠTEFÁNIK, Kremnica, 218.

40 SZENTPÉTERY - BORSA, Az Árpád-házi királyok okleveleinek kritikai, vol. 1/3, p. 396, no. 1398; p. 416, no. 1354; p. 461, no. 1516, and p. 474, no. 1551. For the early history of the landownership in the area, see: MÁLYUSZ, Turóc megye kialakulása, 99-101. BRÁZ, A nagycsepcsényi és muthnai Vladár-család története.

41 For a map of the area, see: ŠIKURA, Miestopisné dejiny Turca.

42 SZENTPÉTERY - BORSA, Az Árpád-házi királyok okleveleinek kritikai, vol. 1/3, p. 416, no. 1354. Its edition: WENZEL, Árpádkori új okmánytár, vol. 8, 56. See also: SZENTPÉTERY - BORSA, Az Árpád-házi királyok okleveleinek kritikai, vol. 1/3, p. 415, no. 1351, its edition: WENZEL, Árpádkori új okmánytár, vol. 8, 55. 
of Nicholas, son of Matthew, with the intent to found a village or villages in order to exploit the resources in the uninhabited forest areas. Nicholas as advocatus received significant benefits, amongst other things two empty plots and a place suitable for a mill (locus molendini) - i.e. the right to build a mill - in the territory of the forest, as well as a place for a mill outside of the forest by the River Turiec, the latter including a plot for the miller's house. ${ }^{43}$ The settling this time was different because the hospites were given the rights of the mining town of Krupina. ${ }^{44}$ However, the advocatus and his heirs had a special right to receive every sixth denar of the taxes the settlers paid to the landlords as well as one sixth of the gifts given to the landlords. Since this latter stipulation is not included in the original privileges of Krupina, this is referred to in the hospes-privilege as a custom of Žilina. Accordingly, while in general, the charter refers to the rights of the settlers as being the same as for the inhabitants of Krupina, in one particular instance the charter still refers to Žilina's privileges as authoritative. ${ }^{45}$

It is no surprise that the nobles of Mutna made major efforts to settle the area in that period and not in the thirteenth century. The rapid growth of close-by Kremnica must have brought previously unprecedented economic benefits for the settlers in the forest. The proximity to Kremnica, however, was not only an economic benefit, but in the long run proved a major threat as well, since the wealthy town, from the beginning of the fifteenth century onwards, made numerous efforts to get ownership of the villages in the area. ${ }^{46}$ Kremnica managed to expand its land holdings in the area, not only in the early fifteenth century, but they continued to do so in the coming century as well. In the late fifteenth century, the landlords of Mutna - referred to as praedium (perhaps meaning, but not necessarily, a lost settlement ${ }^{47}$ ) at the time - claimed that the burghers of Kremnica hired mercenaries to take over their territories. ${ }^{48}$ Not much later, in the 1520s, the authority of Turóc County forbade Kremnica from seizing any part of the village of Felsőmutna. ${ }^{49}$ These efforts clearly testify to Kremnica's strong interest in systematically taking hold over the natural resources in the vicinity of the town, partly to provide themselves with the resources, partly to monopolize the market.

From the point of view of water-management and the possession of mills, one further hospes-settlement is worth mentioning, the village of Dolný Turček, also founded in Mutna Forest. The settlement, lying a few kilometres north of Kremnica, had significant mills as the above-mentioned River Turiec, the most abundant waterway of the area, crossed the village. According to a document from 1371, the settlement had two mills by then, one running with as many as eight wheels and another one with six wheels. ${ }^{50}$ The document, apart from giving information about one of the largest milling complexes in fourteenth-century Hungary, also contains an exceptional clause: it annuls every

43 For locus molendini and its legal implications, see: VADAS, Some Remarks on the Legal Regulations, 291-304. CHIRA, Documentary Evidence on the Uses of Water-Mills, 65-67.

44 Cf. SZENDE, Trust, Authority, and the Written Word, 66, 168 and 219.

45 MNL OL, DF 249547 (for its summary, see: KRISTÓ, Anjou-kori oklevéltár, vol. 48, pp. 287-288, no. 546).

46 On this, see: MÁLYUSZ et al. Zsigmondkori oklevéltár, vol. 2/1, p. 41, no. 328; p. 295, no. 2537; p. 359 , no. 3056; p. 367, no. 3112; pp. 375-376, no. 3181; p. 461, no. 3838; pp. 465-466, no. 3866; vol. 2/2, pp. 36-37, no. 5431; p. 230, no. 6718; vol. 3, p. 217 no. 697.

47 NÓGRÁDY, Az elakadt fejlödés, 11-30.

48 MNL OL, Diplomatikai Levéltár (hereinafter DL) 95 433. (21 August 1498)

49 MNL OL, DL 98 227. (30 March 1525)

50 MATUNÁK, Z dejin Slobodného, pp. 462-463, no. 10. MNL OL, DF 249538. 
previous document issued by Kremnica concerning rights to the river. This passage is important in two respects; first, it strongly contradicts contemporary customary law, which accepts an earlier acquired right as superior to one acquired later in water rights and other spheres of common law. ${ }^{51}$ Second, the document implies there were earlier decisions of Kremnica concerning the rights to water in Dolný Turček, documents that are probably lost. I will refer to the latter problem in the conclusion of the present paper, as this passage may be of crucial importance to the present enquiry. One further problem is worth consideration with regard to this document. The text refers to the location of the two mills on the River Turiec and mentions the six-wheeled one to be at "half water" (unum molendinum sex Rotarum in Turczia inferiori juxta aquam dimidiam situatum, que dicitur am halbem wasser) and the eight-wheeled at "three-quarter" (unum molendinum octo Rotarum situatum in tribus quartalibus aque) in the waterway. This is a rather unique term in Hungarian medieval pragmatic literacy, and one can only guess about its meaning. I think there are two possible interpretations of "half water" and "three-quarter water", the first is that they blocked half and three-quarters of the river respectively, or that they used half and three-quarters of the water of the river. ${ }^{52}$

The last hospes-village that is worth mentioning is Horná Štubňa, called Újlehotka at the time. The name is telling as the word is a compound one, consisting of "új" (meaning "new" in Hungarian) and "lehotka" (a word of Slavic origin, meaning forest clearance, used as a loanword in Hungarian). ${ }^{53}$ The settlers in 1390 were granted the rights of Krupina, and the leader of the settling process, a certain Bartos and his heirs, had the right to build mills freely. ${ }^{54}$

As is evident from the list of settlements discussed above, the burghers of Kremnica acquired significant properties in the vicinity of the mining town and had numerous water-related infrastructural elements, mostly mills, built on these estates.

\subsection{External Interests in Water-Use in Kremnica}

While the burghers of Kremnica seem to have been particularly active in extending their power to the surroundings of their city (leading to many conflicts with the surrounding settlements and their landowners), as well as in having mills built in these areas, the mills within the borders of Kremnica, however, were not exclusively in their own hands. Some of them were owned by burghers whose activities can mostly be attested to in other mining towns. For instance, Nicolas Smyt, a burgher from the nearby Nová Baňa, came into the possession of a, by then, four-wheeled water mill, previously owned by the aforementioned Kadold. ${ }^{55}$ Soon afterwards, Smyt sold the building to a burgher from the town of Louny in Bohemia. ${ }^{56} \mathrm{He}$ was not the only person alien to the town who had a share in the milling industry within the borders of Kremnica. Burghers

51 See: TRINGLI, A magyar szokásjog a malomépítésröl, 251-267. VADAS, Some Remarks on the Legal Regulations.

52 Cf: MNL OL, DF 249 958. Edited in: KRIŽKO, A körmöcbányai római katholikus egyházközség, pp. 40-42, no. 2. For sharing only a proportion of the amount of water, see the Swedish "institution" of the King vein (Kungsådra): JAKOBSSON, Keep the Water Flowing.

53 MELICH, Három helynévröl, 321-324. More recently: KÖRMENDY, Melioratio terrae, 212, 231-232.

54 For an edition of the document, see: MATUNÁK, Z dejin Slobodného, pp. 463-464, no. 11.

55 MNL OL, DF 249 435. For further investments from Nová Baňa at Kremnica, see: MNL OL, DF 276184.

56 See further, on the interests of the burghers of Nová Baňa in the mills of Kreminca: MNL OL, DF 249 443. Cf. ŠTEFÁNIK, Nová Baňa, 298. 
from Buda, ${ }^{57}$ as well as the archbishopric of Esztergom owned a significant number of mills in the mining town. The latter institution got its hands on a large mill in the town in the 1460 s, after which they leased it to Kremnica. They bought the mill for 4000 (!) florins and leased it back to the town for as much as 300 golden florins a year, ${ }^{58}$ the greatest single source of income from mills in the whole of the archbishopric. ${ }^{59}$

Apart from the fact that several mills were owned by individuals other than the burghers of Kremnica, including the largest of such mills in the town, there were more mills for grinding grain and to crush the ore mined locally in the burghers' hands. The well-preserved fifteenth-century account books of the town usually registered the mills and their owners precisely (see Fig. 2), also noting by which of the two abovementioned streams (in the Soler and Collner valleys) the mill was functioning. Although a detailed analysis of the individual mills would reveal something regarding the historical topography of the town, from the viewpoint of this paper it is less relevant. However, their very existence is certainly important for understanding the importance of water in the life of the town in general.

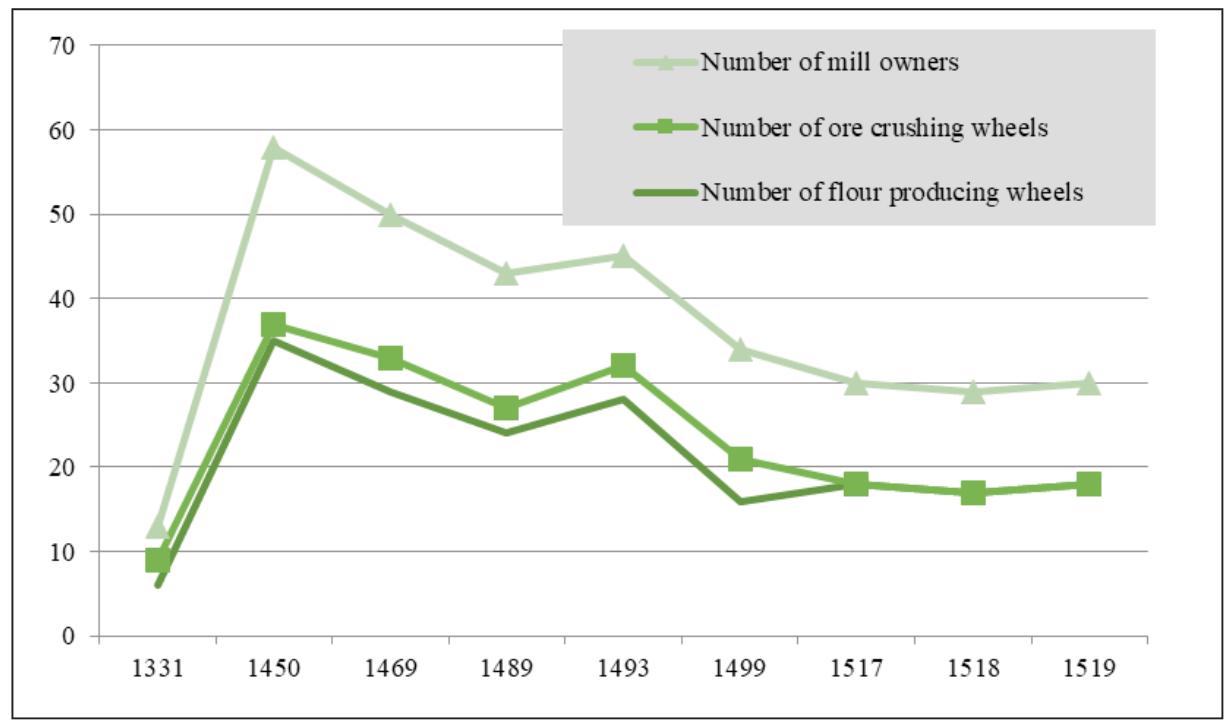

Figure 2: The mills of Kremnica and their ownership (1331-1519) ${ }^{60}$

57 MATUNÁK, Eredeti oklevelek a körmöczbányai püspöki malomról, 321-324. See also: KUBINYI, A budai német patriciátus, 496.

58 FÜGEDI, Az esztergomi érsekség gazdálkodása, 102-103, and 536. For the incomes, and the lease more recently: KUFFART, Az esztergomi érsek pisetum-jövedelme, 100 and 109.

59 On the acquisition of the mill, see: MATUNÁK, Eredeti oklevelek, pp. 324-326, no. 5.

60 FEJÉRPATAKY, Magyarországi városok régi számadáskönyvei, 625-626 (1442-1443), 625-636 (1450). MNL OL, DF 250101 (1469), MNL OL, DF 250088 (1489), MNL OL, DF 250090 (1499), MNL OL, DF 250102 (1517), MNL OL, DF 250076 (1518), MNL OL, DF 250077 (1519). 
The studied account books revealed that in the late medieval period, Kremnica and its surrounding settlements had an extremely dense network of water-related infrastructure despite the limited water resources within the immediate borders of the town. This certainly put pressure on the waterways. The quality of the water would have been endangered by the mining activity, ${ }^{61}$ as well as the other craft activities ${ }^{62}$ in Kremnica, while the many corn mills certainly caused periodic shortages in the quantity that reached the downstream parts of the city.

\subsection{Kremnica and the Legal Environment of Water-Use}

Some lessons can be drawn based on the data discussed above. First, from the beginning of the existence of the town, the burghers of Kremnica possessed several water mills. In the light of the 1331 pledge contract, it may be well worth considering that even if the privilege granted to Kremnica in 1328 did not refer to this right explicitly, the settlers from other areas lived with this freedom in practice. The existence of the freedom to use waterways to erect mills is confirmed by the fact that hospes-villages founded under the leadership of Kremnica were also granted this freedom. Otherwise, the advocati from the different hospes-villages would have acquired more freedoms than the burghers who commissioned them to lead the settling of the villages. The above-discussed 1371 document on Dolný Turček is of crucial importance here, as it shows that the town of Kremnica had already proceeded with their own water rights before the end of the fourteenth century.

It was probably one of the crucial elements in settling the area to provide the settlers with the use of the waterways for their benefit. Having mills built in the settlements right after their foundation to grind grain and process the ore mined in the area, as well as for preparing timber for the building of the mine shafts, was already a crucial issue. Accordingly, despite the fact that in the charters of privilege of mining towns in medieval Hungary the rights to construct mills and use water resources in general only rarely appear in charters, such questions are discussed in the early legal documents of the settlements with a strikingly high frequency. This is also true in the case of the early pragmatic written documents from Kremnica, where up the early fifteenth century almost half of the documents issued by the authority of the two towns contain references to water-related issues. ${ }^{63}$

\section{Outlook: Lasting Heritage of the Land Use in a Mining Town}

Water was certainly one of the most contested resources in the surroundings of medieval mining settlements because of the manyfold uses of this resource. This contested nature of the resource is certainly not unique: struggles for the exploitation of the forests was probably similarly strong and lasted well beyond the Middle Ages. ${ }^{64}$ The lasting exploitation of the gold and silver deposits seems to have put a great pressure both on forest and water resources. This can be attested to centuries after the heyday of the mining activity in the Kremnica area. In the eighteenth century, when the Lutheran pastor, and the author of the most detailed description of Hungary

61 Cf. WERTHER et al. On the Way to the Fluvial Anthroposphere.

62 ŠTEFÁNIK, Kremnica, 224-227. For the pressure of craft activities on minor waterways, such as those at Kreminca, see: VADAS - FERENCZI, Nagyvárosi kisvizek.

63 SZENDE, Királyi kényszer vagy közösségi akarat, 522, and 535-536 (Appendix).

64 WENZEL, Az alsómagyarországi bányavárosok küzdelmei. 
at the time, Matthias Bel surveyed the area, he took note of the major infrastructural works that had been undertaken in Kremnica and its surroundings. ${ }^{65} \mathrm{He}$ describes Kremnica's waterways as follows:

The Lower Town is cut by the Kremnica Stream of which we already took note. This is where the stream bends from north towards the east. Numerous buildings were built along this stream, not only mining machines but also a famous corn mill. The stream originates in three springs. The first is the eastern one, which breaks up at the area called Sohler-Grund. With different gutters, its current is divided into two branches. The first runs towards the south, to the Lower Town, but before reaching that, it drives papermills, then meandering in a small channel finds its way back to the main current under the gardens of the town. The other branch of the spring is diverted by channels built on the hillside, and then is directed to underground pipes to provide the town houses with water. [...] From the springs the second and the third are to the north and to the east from the town. The latter, probably because of the colour of its water is called Schwartz-Wasser. They both run in channels dug and drilled into the side of the hills with large investments, and running long, taking meanders they arrive at the village of Berg [Johannesberg]. [...] Then, part of the water is used in dewatering machines, elsewhere, they drive ore-crushers. [...] There, within the territory of the village of Berg, the stream splits into two parts, a lower and an upper. [...] The other branch of the stream then reaches the valley of Kremnica at a place called Neu Grund, where it rejoins the upper branch. Here it constantly runs the ore-crushers of the emperor and mine-lessees and even some of the machines of the mint. The waters that run out from the channels in the valley of Berg are gathered by a separate bed, which then runs to the corn mill of the bishop, in the meantime providing water for some workshops, though smaller than the ones mentioned before. ${ }^{66}$

This rather long passage from Bel's work testifies to a significantly modified riverscape both in the town of Kremnica and in the surroundings of the town. By the 1720s, when the spine of Bel's work was gathered, the heyday of mining was well over. ${ }^{67}$ By this time the higher lying mine-shafts had been run down for centuries, and the deeper lying, more expensive shafts had to be used, which made significant further works - such as large-scale dewatering - necessary. Despite the growing expense in reaching the lower lying gold and silver deposits, and temporary crises of mining at Kremnica and elsewhere in Slovakia, the Kremnica Chamber still proved to be a highly profitable enterprise well up to the nineteenth century. ${ }^{68}$ This profitability led to a seriously transformed waterscape, and although this falls outside of the scope of the primary focus of the study, the forests around the town as well. ${ }^{69}$

65 BELIUS, Notitia Hungariae novae, vol. 4, 155-290.

66 BELIUS, Notitia Hungariae novae, vol. 4, 210.

67 TÓTH, Bél Mátyás.

68 KENYERES, A bányakamarák szerepe, 177-188. KENYERES, A Magyar és a Szepesi Kamara bevételei, 3-67.

69 MAGYAR, A feudalizmus kori erdögazdálkodás. 
The environmental heritage of modern mining activities received considerable attention in Central Europe and elsewhere in the past decades. ${ }^{70}$ Some of these works drew attention to the fact that the landscape transformation caused by the mining activities goes well beyond the scars in the land itself, but that deforestation was similarly important. Some aspects, especially water contamination, has been highlighted in connection to some of the mining technologies (use of cyanide in gold mining to mention but one); however, less attention has been paid to the environmental change of riverscapes and floodplain areas in pre-modern mining landscapes. The main problem in many cases was not - or not only - the contamination, but the number of infrastructural elements that mining, and the population attracted by mining, necessitated along waterways. This, combined with the deforestation related to mining created a space that was certainly vulnerable, prone to flash floods, as well as leading to constant struggles for water as a resource. To understand this complex heritage of mining before modern times, many more case studies on individual resources and on study sites would be truly important.

\section{BIBLIOGRAPHY}

\section{Primary sources}

Magyar Nemzeti Levéltár Országos Levéltára [Hungarian National Archives], Diplomatikai Levéltár [Diplomatics Archive]

Magyar Nemzeti Levéltár Országos Levéltára [Hungarian National Archives], Diplomatikai Fényképgyüjtemény [Diplomatic Photocopy Collection]

\section{Secondary sources}

BATIZI, Zoltán. "Mining in Medieval Hungary.” In: LASZLOVSZKY, József et al. (eds.) The Economy of Medieval Hungary (East Central and Eastern Europe in the Middle Ages, 4501450, vol. 49). Boston; Leiden: Brill, 2018, pp. 166-181.

BELIUS, Matthias. Notitia Hungariae novae historico-geographica. Vol. 1-5. Viennae: Paulus Strabius; J. P. van Ghelen, 1735-1749.

BORSA, Iván. A Szent-Iványi család levéltára 1230-1525. (Magyar Országos Levéltár kiadványai, II. Forráskiadványok, 14). Budapest: MOL, 1988.

BRÁZ, Béla. A nagycsepcsényi és muthnai Vladár-család története és leszármazása.

Turócszentmárton: Magyar Ny., 1907.

CEMBRZYŃSKI, Pawel. "Gold Rush" or "Considered Investment"? Origins of Mining Towns in the Medieval Central Europe. In: Acta rerum naturalium, 2017, vol. 21, pp. 59-72.

CHIRA, Alexandra. Documentary Evidence on the Uses of Water-Mills in Medieval Transylvania: A Case Study of the River Someş. In: MIELZAREK, Christoph ZSCHIESCHANG, Christian (eds.). Usus aquarum: interdisziplinäre Studien zur Nutzung und Bedeutung von Gewässern im Mittelalter. Wien: Böhlau, 2019, pp. 51-70.

ČELKO, Mikuláš (ed.). Das Stadt- und Bergrecht von Kremnitz: Handschriften des Kremnitzer Stadtbuches aus den Jahren (1492), 1504, 1512, 1530, 1537. Košice: Banská Agentúra, 2004. FEHÉRTÓI, Katalin. RATA és TILO. In: Magyar Nyelvốr, 1998, vol. 122, pp. 64-67. FEJÉRPATAKY, László. Magyarországi városok régi számadáskönyvei (Selmeczbánya, Pozsony, Beszterczebánya, Nagyszombat, Sopron, Bártfa és Körmöczbánya városok levéltáraiból). Budapest: Magyar Tudományos Akadémia, 1885.

FERENCZI, László - LASZLOVSZKY, József - PINKE, Zsolt - SZABÓ, Péter - VADAS, András. Long-Term Environmental Changes in Medieval Hungary: Changes in Settlement

70 See e.g. two collected volumes: UEKOETTER, Mining in Central Europe. MCNEILL - VRTIS, Mining North America. 
Areas and Their Potential Drivers. In: LASZLOVSZKY, József et al. (eds.). The Economy of Medieval Hungary (East Central and Eastern Europe in the Middle Ages, 450-1450, vol. 49). Boston; Leiden: Brill, 2018, pp. 37-47.

FRÖHLICH, Jiří. Středověké a raně novověké mlýny na zlatou rudu v Čechách. In: Zlatá stezka, 2017, vol. 24, pp. 205-219.

FÜGEDI, Erik. Az esztergomi érsekség gazdálkodása a XV. század végén. I-II. In: Századok, 1960 , vol. 94, pp. 82-124, and 505-555.

FÜGEDI, Erik. Középkori magyar városprivilégiumok. In: Tanulmányok Budapest Múltjából, 1961, vol. 14, pp. 17-107.

GYÖRFFY, György. Az Árpád-kori Magyarország történeti földrajza, Vol. 1-4. Budapest: Akadémiai, 1963-1998.

Ius regale montanorum. In: JIREČEK, Hermenegildus (ed.). Codex juris Bohemici. Praha: Kober, 1867, pp. 266-435.

JAKOBSSON, Eva. Keep the Water Flowing! Premodern Swedish Water Management. In: DOWLING, Abigail P. - KEYSER, Richard (eds.). Conservation's Roots Managing for Sustainability in Preindustrial Europe, 1100-1800 (The Environment in History: International Perspectives, vol. 19). New York: Berghahn, 2021, pp. 178-200.

JAN, Libor. Václav II. a struktury panovnické moci. Brno: Matice moravská, 2006.

JUCK, Lubomír (ed.). Výsady miest a mestečiek na Slovensku. I. 1238-1350. Bratislava: Veda, 1984.

KENYERES István. A Magyar és a Szepesi Kamara bevételei és kiadásai a XVII. században. In: Fons, 2017, vol. 24, no. 1, pp. 3-67.

KENYERES, István. A bányakamarák szerepe a Magyar Királyság jövedelmeiben a XV-XVI. században. In: MIKÓ, Gábor - PÉTERFI, Bence - VADAS, András (eds.). Tiszteletkör. Történeti tanulmányok Draskóczy Istuán egyetemi tanár 60. születésnapjára. Budapest: ELTE Eötvös Kiadó, 2012, pp. 177-188.

KISS, Lajos. Földrajzi nevek etimológiai szótára. Budapest: Akadémiai, 1978.

"Komorskí grófi Kremnice”. Accessed 25 September 2021. http://www.corycats.sk/mint/index. php?go=grofi_is.

KÖRMENDY, Adrienne. Melioratio terrae: vergleichende Untersuchungen über die Siedlungsbewegung im östlichen Mitteleuropa im 13.-14. Jahrhundert (Prace Komisji historycznej / Poznańskie Towarzystwo przyjaciót nauk, Wydziat historii i nauk społecznych, vol. 48). Poznań: Wydawn. Poznańskiego Towarzystwa przyjaciół nauk, 1995.

KRISTÓ, Gyula et al. (eds.). Anjou-kori oklevéltár, Vol. 1-50. Szeged; Budapest: JATE - MNL OL, 1990-2020.

KRIŽKO, Pál. A körmöcbányai római katholikus egyházközség története. I. korszak: 1317-1520. Budapest: Rudnyánszky, 1887.

KUBINYI, András. A budai német patriciátus társadalmi helyzete családi összeköttetései tükrében a 13. századtól a 15. század második feléig. In: KUBINYI, András. Tanulmányok Budapest középkori történetéról, Vol. 1-2 (Várostörténeti tanulmányok, vol. 10). Budapest: Budapest Fóváros Levéltára, 2009, Vol. 2, pp. 457-512. (published earlier under the same title at: Levéltári közlemények, 1971, vol. 42, pp. 203-269.).

KUFFART, Hajnalka. Az esztergomi érsek pisetum-jövedelme Battyányi István udvarbíró idején. In: KÁDAS, István - SKORKA, Renáta - WEISZ, Boglárka (eds.). Veretek, utak, katonák. Gazdaságtörténeti tanulmányok a magyar középkorról. Budapest: Bölcsészettudományi Kutatóközpont, 2018, pp. 93-111.

LUCAS, Adam Robert. Industrial Milling in the Ancient and Medieval Worlds: A Survey of the Evidence for an Industrial Revolution in Medieval Europe. In: Technology and Culture, 2005, vol. 46 , no. 1 , pp. $1-30$.

LUCAS, Adam. Wind, Water Work: Ancient and Medieval Milling Technology (Technology and Change in History, vol. 8). Leiden; Boston: Brill, 2006.

MAGYAR, Eszter. A feudalizmus kori erdógazdálkodás az alsó-magyarországi bányavárosokban, 1255-1747. Budapest: Akadémiai, 1983. 
MALINIAK, Pavol et al. Lesy v dejinách Zvolenskej stolice. Lesné remeslá v kultúre a zamestnaní obyvatelstva $v$ stredoveku a ranom novoveku. Banská Bystrica; Kraków: Lesy Slovenskej republiky; Spolok Slovákov v Polsku, 2011.

MÁLYUSZ, Elemér et al. (eds.). Zsigmondkori oklevéltár, Vol. 1-14 (Magyar Országos Levéltár kiadványai, II. Forráskiadványok 1, 3-4, 22, 25, 27, 37, 39, 41, 43, 49, 52, 55, 59). Budapest: Akadémiai, 1951-2020.

MÁLYUSZ, Elemér. Turóc megye kialakulása. 2nd ed. Máriabesnyő; Gödöllő: Attraktor, 2005. MATUNÁK, Michal. $Z$ dejin Slobodného a Hlavného Banského Mesta Kremnice. Kremnica: Slobodné a hlavné banské mesto, 1928.

MATUNÁK, Mihály. Eredeti oklevelek a körmöczbányai püspöki malomról. In: Magyar Történelmi Tár, 1907, vol. 8, pp. 321-326.

MCNEILL, John Robert - VRTIS, George (eds.). Mining North America: An Environmental History since 1522. Berkeley: University of California Press, 2017.

MELICH, János. Három helynévről: Lehota, Vólya, Ohába. In: Századok, 1907, vol. 41, pp. 321-324.

MINÁRČIC, Miroslav. Metačná listina svätoantonského panstva z roku 1266 a jej výpovedná hodnota k dejinám banskoštiavnického baníctva. In: Montánna história, 2009, vol. 2, pp. $46-69$.

NÓGRÁDY, Árpád. Az elakadt fejlődés. In: TÓTH, Norbert C. - NEUMANN, Tibor (eds.). Keresztesekból lázadók. Tanulmányok 1514 Magyarországáról. Budapest: MTA BTK Történettudományi Intézet, 2015, pp. 11-30.

PAULINYI, Oszkár. A Garam-vidéki bányavárosok lakosságának lélekszáma a XVI. század derekán. In: Történelmi Szemle, 1958, vol. 1, pp. 351-378.

PFEIFER, Guido. Ius regale montanorum: ein Beitrag zur spätmittelalterlichen Rezeptionsgeschichte des römischen Rechts in Mitteleuropa. Ebelsbach: Aktiv Druck \& Verlag, 2002.

STERNBERG, Kaspar. Umrisse einer Geschichte der böhmischen Bergwerke. Praha: Haase, 1836-1837.

STRÄTZ, Hans-Wolfgang. Kuttenberger Bergordnung. In: AUTY, Robert et al. (eds.). Lexikon des Mittelalters, Vol. 5. München: Artemis, 1991, p. 1594.

SZABÓ, Péter. The Extent and Management of Woodland in Medieval Hungary. In:

LASZLOVSZKY, József et al. The Economy of Medieval Hungary (East Central and Eastern Europe in the Middle Ages, 450-1450, vol. 49). Boston; Leiden: Brill, 2018, pp. 219-237.

SZENDE, Katalin. A magyar városok kiváltságolásának kezdetei. In: BÁRÁNY, Attila Pál PAPP, Klára - SZÁLKAI, Tamás (eds.). Debrecen város 650 éves: Várostörténeti tanulmányok (Speculum Historiae Debreceniense, vol. 7). Debrecen: DE BTK Történelmi Intézet, 2011, pp. $32-56$.

SZENDE, Katalin. Iure Theutonico? German Settlers and Legal Frameworks for Immigration to Hungary in an East-Central European Perspective. In: Journal of Medieval History, 2019, vol. 45, no. 3, pp. 360-379. https://doi.org/10.1080/03044181.2019.1612195.

SZENDE, Katalin. Királyi kényszer vagy közösségi akarat? Hivatali írásbeliség a magyarországi bányavárosokban a 13-14. században. In: WEISZ, Boglárka - SKORKA, Renáta - KÁDAS, István (eds.). Márvány, tárház, adomány. Gazdaságtörténeti tanulmányok a magyar középkorról. Budapest: MTA BTK Történettudományi Intézet, 2019, pp. 507-540.

SZENDE, Katalin. Mennyit ér a kiváltság? Városprivilégiumok kibocsátása és rendelkezéseik betartása I. Károly alatt. In: WEISZ, Boglárka (ed.). Pénz, posztó, piac. Gazdaságtörténeti tanulmányok a magyar középkorról. Budapest: MTA BTK Történettudományi Intézet, 2016, pp. 285-340.

SZENDE, Katalin. Power and Identity. Royal Privileges to the Towns of Medieval Hungary in the Thirteenth Century. In: IRSIGLER, Franz - PAULY, Michel (eds.). Urban Liberties and Citizenship from the Middle Ages up to Now/Libertés et citoyenneté urbaines du moyen âge à nos jours. (Beiträge zur Landes- und Kulturgeschichte, vol. 9) Trier: Porta Alba, 2015, pp. $27-68$. 
SZENDE, Katalin. Trust, Authority, and the Written Word in the Royal Towns of Medieval Hungary. (Utrecht Studies in Medieval Literacy, 41) Turnhout: Brepols, 2018.

SZENTPÉTERY, Imre - BORSA, Iván (eds.). Az Árpád-házi királyok okleveleinek kritikai jegyzéke / Regesta regum stirpis Arpadianae critico-diplomatica. Vol 1-2. Budapest: Akadémiai, 1923-1987.

ŠIKURA, Ján Št. Miestopisné dejiny Turca. Bratislava: Slovenská akadémia vied a umení, 1944.

ŠTEFÁNIK, Martin - LUKAČKA, Ján (eds.). Lexikon stredovekých miest na Slovensku. Bratislava: Historický Ustav SAV, 2010.

ŠTEFÁNIK, Martin. Italian Involvement in Metal Mining in the Central Slovakian Region from the Thirteenth Century to the Reign of King Sigismund of Hungary. In: I Tatti studies, 2011-2012, vol. 14/15, pp. 11-46.

ŠTEFÁNIK, Martin. Kremnica. In: ŠTEFÁNIK, Martin - LUKAČKA, Ján (eds.). Lexikon stredovekých miest na Slovensku. Bratislava: Historický Ustav SAV, 2010, pp. 217-241.

ŠTEFÁNIK, Martin. Nová Baňa. In: ŠTEFÁNIK, Martin - LUKAČKA, Ján (eds.). Lexikon stredovekých miest na Slovensku. Bratislava: Historický Ustav SAV, 2010, pp. 294-306.

TEKE, Zsuzsa. L'energia idraulica nella siderurgia medioevale ungherese. In: CAVACIOCCHI, Simonetta (ed.). Economia e energia sec. XIII-XVIII. Atti della "Trentaquattresima Settimana di Studi”, 15-19 aprile 2002. Firenze: Le Monnier, 2003, pp. 335-341.

TÓTH, Gergely. Bél Mátyás „Notitia Hungariae novae...” címú müvének keletkezéstörténete és kéziratainak ismertetése. PhD diss. Eötvös Loránd Tudományegyetem, 2007.

TRINGLI, István. A magyar szokásjog a malomépítésről. In: NEUMANN, Tibor (ed.).

Tanulmányok a középkorról (Analecta Medievalia, vol. 1). Budapest; Piliscsaba: PPKE, 2001, pp. 251-267.

UEKOETTER, Frank (ed.). Mining in Central Europe. Perspectives from Environmental History. (Rachel Carson Center. Pespectives, vol. 10) Munich: Rachel Carson Center, 2012.

VADAS, András - FERENCZI, László. Nagyvárosi kisvizek és a városi környezet az iparosodás elött. In: Magyar Gazdaságtörténeti Évkönyv 2021 (in press).

VADAS, András. A középkori Magyar Királyság bányavárosai és a malmok különös tekintettel Körmöc- és Újbányára. In: WEISZ, Boglárka - SKORKA, Renáta - KÁDAS, István (eds.). Márvány, tárház, adomány. Gazdaságtörténeti tanulmányok a magyar középkorról. Budapest: MTA BTK Történettudományi Intézet, 2019, pp. 483-506.

VADAS, András. Geography, Natural Resources and Environment. In: ZEČEVIĆ, Nada ZIEMANN, Daniel (eds.). Oxford Handbook of Medieval Central Europe. Oxford: Oxford University Press, 2022. (in press).

VADAS, András. Some Remarks on the Legal Regulations and Practice of Mill Construction in Medieval Hungary In: HUBER-REBENICH, Gerlinde - ROHR, Christian - STOLZ, Michael (eds.). Wasser in der mittelalterlichen Kultur / Water in Medieval Culture Gebrauch Wahrnehmung - Symbolik/Uses, Perceptions, and Symbolism. Berlin: De Gruyter, 2017, pp. 291-304.

VAVRUŠKOVÁ, Kateřina. Po stopách mlynářů v Kutné Hoře. In: Krásné Město, 2011, no. 2, pp. 14-18. Accessed 6 October 2021. https://www.cms-kh.cz/po-stopach-mlynaru-v-kutnehore.

"Vodnimlyny". Accessed 6 October 2021. http://vodnimlyny.cz.

WEISZ, Boglárka. A bányaváros mint önálló várostípus a 14. században. In:

Bányászattörténeti Közlemények, 2015, vol. 19, pp. 31-57.

WEISZ, Boglárka. A nemesércbányászathoz kötődő privilégiumok az Árpád- és az Anjoukorban. In: Történelmi Szemle, 2008, vol. 50, no. 2, pp. 141-161.

WEISZ, Boglárka. Az alsó-magyarországi bányavárosok kiváltságai a Zsigmond-korban. In: Urbs. Magyar Várostörténeti Évkönyv, 2018, vol. 12, pp. 21-48.

WEISZ, Boglárka. Mining Town Privileges in Angevin Hungary. In: Hungarian Historical Review, 2013, vol. 2, no. 2, pp. 288-312.

WENZEL, Gusztáv (ed.). Árpádkori új okmánytár. Vol. 1-12. Pest; Budapest: Eggenberger Ferdinánd, 1860-1874. 


\section{THECCITY and}

WENZEL, Gusztáv. Az alsómagyarországi bányavárosok küzdelmei a nagy-lucsei Dóczyakkal, 1494-1548 (Értekezések a történeti tudományok köréből, vol. 6/6). Budapest: Magyar Tudományos Akadémia, 1876.

WERTHER, Lukas - MEHLER, Natascha - SCHENK, Gerrit Jasper - ZIELHOFER, Christoph. On the Way to the Fluvial Anthroposphere: Current Limitations and Perspectives of Multidisciplinary Research. In: Water, 2021, vol. 13(16), Art. no. 2188. https://doi. org/10.3390/w13162188.

ZYCHA, Adolf. Das böhmische Bergrecht des Mittelalters. Vol 1-2. Berlin: Vahlen, 1900. ZSOLDOS, Attila. Károly és a városok. In: WEISZ, Boglárka (ed.). Pénz, posztó, piac. Gazdaságtörténeti tanulmányok a magyar középkorról. Budapest: MTA BTK Történettudományi Intézet, 2016, pp. 267-283.

ZSOLDOS, Attila. Sienai ötvösből szepesi alispán. Olaszok és itáliaiak a Druget-nádorok szolgálatában. In: Világtörténet, 2017, vol. 7 [39], pp. 53-74. 